\title{
Disease Cycle, Development and Management of Sclerotinia Stem Rot of Potato
}

\author{
Dennis A. Johnson"1, Zahi K. Atallah ${ }^{2}$ \\ ${ }^{1}$ Department of Plant Pathology, Washington State University, Pullman, USA \\ ${ }^{2}$ Hartnell College, Salinas, USA \\ Email: dajohn@wsu.edu
}

Received 21 October 2014; Revised 20 November 2014; accepted 1 December 2014

Copyright (C) 2014 by authors and Scientific Research Publishing Inc.

This work is licensed under the Creative Commons Attribution International License (CC BY). http://creativecommons.org/licenses/by/4.0/

cc) (i) 0 pen Access

\section{Abstract}

Potato is severely affected by Sclerotinia sclerotiorum in the US Pacific Northwest (PNW) and satisfactory disease management has not been achieved until recently. Recent research has given a better understanding of key epidemiological factors which has resulted in improved disease management in the PNW. This work reviews the epidemiology of Sclerotinia stem rot and highlights information that has led to the better management of the disease on potato. The primary source of inoculum of Sclerotinia sclerotiorum for potato in the Columbia Basin of the PNW are ascospores produced within potato fields or carried by wind currents from neighboring fields planted to winter cereals or other crops. Ascospores are ejected from apothecia and disseminated throughout the Columbia Basin over an extended time period. Immature apothecia generally first emerge at or shortly after row closure in potato fields in the Columbia Basin. Ascospores of $S$. sclerotiorum are incapable of direct infection of intact green potato tissues, and flower blossoms are crucial for infection and development of the disease in potato. Airborne ascospores are deposited on open potato blossoms still attached to the canopy. Infested flowers fall and are trapped on stems, usually leaf axils, or fall on the ground, and fungal mycelia then rapidly colonize the blossoms when humidity is high in the plant canopy. Ascospores are also deposited on senescent and dead plant material on the ground, germinate, and produce mycelium. Infection occurs shortly after contaminated blossoms become lodged on stems in the plant canopy, or after stems come in contact with contaminated fallen blossoms or decomposing plant tissues on the ground. Infection can occur within 3 days after contact of contaminated blossoms with green tissue. Lesions initially appear on potato stems 14 to 30 days after row closure and 12 to 20 days following full bloom of primary inflorescences of potato in the Columbia Basin. Significant levels of outcrossing sexual recombination have been found in the homothallic $S$. sclerotiorum population in the Pacific Northwest. Sclerotinia stem rot of potato is best managed by using an integrated approach of combining cultural practices that produce optimum plant foliar development without producing an excessive crop canopy, irrigation management to avoid excessive amounts of irrigation water, and 
timely applications of fungicides. Contaminated flower blossoms served as a bridge for infection and fungicides applied before contaminated blossoms drop on foliage most effectively reduce infections on stems. Improved disease management has been achieved by timing fungicides to coincide with full bloom of primary inflorescences.

\section{Keywords}

White Mold, Sclerotinia Sclerotiorum, Epidemiology and Fungicide Application Timing

\section{Introduction}

Sclerotinia sclerotiorum (Lib.) de Bary, the cause of Sclerotinia stem rot or white mold of potato, is a necrotrophic, inoperculate discomycete of global distribution. The fungus is among the most non-specific of plant pathogens infecting mostly herbaceous plants of diverse phylogenetic backgrounds including more than 400 species in 75 plant families. Cultivated crops susceptible to S. sclerotiorum include potato, bean, soybean, pea, carrot, cucurbits, sunflower, lettuce, cucurbits and mustards. Susceptible weeds include chickweed, redroot pigweed, dandelion and wild clover. Grasses and cereals are not affected [1]. The fungus is both soil- and airborne. Sclerotia serve as survival structures in the soil and ascospores are the means of aerial dispersal. While the disease is prevalent in potato in the US Pacific Northwest (PNW), its impact is more limited and its occurrence is sporadic in potatoes in Midwestern US states. The disease is primarily promoted by an extensive canopy growth which increases humidity and extends leaf wetness within crop canopies. Increased disease incidences is associated with overhead sprinkler irrigation, a non-upright cultivar architecture, high crop density, close row width, continuous plant surface wetness and excess nitrogen fertilization in potato and other crops [2]-[8].

Satisfactory management of Sclerotinia stem rot on potato has not been achieved in the PNW until recently. Research since 2003 has yielded a better understanding of key epidemiological factors which has resulted in improved disease management. This work reviews the epidemiology of Sclerotinia stem rot and highlights information that has led to the better management of the disease on potato.

\section{Disease Cycle}

Sclerotinia sclerotiorum is typified by the lack of conidia and the generation of sclerotia and tan-colored, cup- or funnel-shaped apothecia generally $2-10 \mathrm{~mm}$ in diameter [9]. Sclerotia form from the agglomeration of hyphae in colonized plant tissues. Eight hyaline, unicellular ascospores are produced per ascus.

The first symptoms on potato appear as watersoaked spots usually at stem and branch axils or on branches or stems in contact with the soil. A white cottony growth of fungus mycelium develops on the lesion, and the infected tissue becomes soft and watery. Lesions often expand in size rapidly following establishment and may girdle the stem which causes the foliage to wilt. Lesions become dry and will turn beige, tan or bleached white in color and papery in appearance. Hard, irregularly shaped sclerotia form in and on decaying plant tissues. They are generally 2 - $4 \mathrm{~mm}$ in diameter and up to $25 \mathrm{~mm}$ long, initially white to cream in color but become black with age, and are frequently found in the hollowed-out center of infected stems. Sclerotia eventually fall to the ground, and are incorporated into the soil during tillage.

Sclerotia are melanized resistant structures capable of withstanding adverse environmental conditions including pesticides and enable the fungus to survive from season to season. They can persist at least 3 years buried in the soil in the absence of a favoring environment for germination. Sclerotia act as a means of pathogen dispersal within fields and over long distances. Because of their size, shape and color, sclerotia are commonly disseminated with the seed of a large number of crops, such as bean or pea. Additionally, the transfer of soil, tillage, agricultural equipment and even water can disseminate sclerotia.

Sclerotia require a conditioning period of cool temperature before germination, and either germinates directly by producing mycelium or carpogenically by producing apothecia [10]. Only the sclerotia in approximately the top $5 \mathrm{~cm}$ of the soil are biologically active, sclerotia at lower depths remain dormant. An accumulation of thermal degree days and moist soil, but not water-saturated soil, are required for germination [11] [12]. Direct germination usually occurs before row closure and the mycelium infects the crown area of potato plants in the 
immediate vicinity, usually a distance of less than $1.5 \mathrm{~cm}$. Apothecia emerge from shallowly buried sclerotia in shaded and moist soils under plant canopies [13] [14]. Multiple apothecia may emerge from a single sclerotium. Apothecia remain functional for 5 - 10 days under shaded conditions in the field and can produce up to 30 million ascospores [14]. Infection of potato is mostly indirectly through ascospores, as is the case with most hosts [11] [15] [16], and apothecial production through carpogenic germination of sclerotia is a fundamental part of the pathogen's disease cycle.

Ascospores are forcibly ejected in mass from the asci in visible puffs of tens of thousands of ascospores. Decreases in relative humidity close to the apothecia are credited for the "puffing" of ascospores [14] [17]. Ascospore releases usually peak around midday and plummet late in the afternoon and at night [4] [18]. Apothecial production and ascospore releases may be staggered over an extended period of several weeks, especially given that soil shading and availability of moisture are required for carpogenic germination. Ascospores are deposited in potato fields in the Columbia Basin from May to mid-July, which precedes row closure by several weeks and extends beyond full bloom of primary flower inflorescences. The number of airborne ascospores decline after full bloom, but increase again in the fall when canola and other mustards are large enough to shade the soil [19].

Ascospores of $S$. sclerotiorum are associated with short and medium range dispersal. Aerial dispersal of ascospores can reach up to 3 - 4 kilometers, but up to 90\% of ascospores are thought to be deposited within 100 150 meters from the source [14] [20]-[22]. Viable ascospores have been captured at $6000 \mathrm{~m}$ in altitude [23], which indicates a potential dissemination over long distances. Non-germinated ascospores can survive up to 12 days in the crop canopy depending on location in the canopy and environmental conditions. Increasing temperatures above $21 \mathrm{C}$ and exposure to ultraviolet radiation increase ascospore mortality [24]. White mold epidemics in bean and rapeseed occurring early in the season have been traced back to ascospores produced by apothecia in neighboring fields cropped to winter crops [23] [25] [26].

The primary source of inoculum for potato in the Columbia Basin are ascospores produced within potato fields or carried by wind currents from neighboring fields planted to winter cereals or other crops. Fields adjacent to current-season potatoes are generally in rotation with potato or other crops susceptible to S. sclerotiorum and may contain numerous sclerotia. Apothecia are produced in these fields as well as in association with weed hosts in non-cropped land areas adjacent to potato fields. Timing of apothecia development varies among fields and depends on degree of shade due to crop development, soil moisture and temperature [11] [12]. Immature apothecia generally first emerge at or shortly after row closure in potato fields in the Columbia Basin.

Ascospores of S. sclerotiorum are incapable of direct infection of intact green potato tissues, but they must first colonize flowers or senescing or dead plant tissues and then use them as an energy source to infect green tissues [5] [14] [26]. Blossoms are crucial for infection and development of Sclerotinia stem rot in potato. Airborne ascospores are deposited on open potato blossoms still attached to the canopy [19]. Infested flowers fall and are trapped on stems, usually leaf axils, or fall on the ground, and fungal mycelia then rapidly colonize the blossoms when humidity is high in the plant canopy. Ascospores are also deposited on senescent and dead plant material on the ground, germinate, and produce mycelium. Infection occurs shortly after contaminated blossoms become lodged on stems in the plant canopy, or after stems come in contact with contaminated fallen blossoms or decomposing plant tissues on the ground (Figure 1). Secondary spread to additional stems may occur when green stems lodge or lean onto actively expanding lesions on infected stems. Flowers and other senescing tissues colonized by ascospores are generally the cause of the vast majority of lesions as opposed to infections near the soil line initiated by mycelium from soil-borne sclerotia [19].

Flower removal before blossom drop drastically reduced disease incidence compared to potato plants in control plots where blossoms were not removed and gives further evidence of the role of flower blossoms as a bridge for infection (Atallah and Johnson, 2004). Similarly, presence of ascospores on flower petals of canola was positively correlated with disease occurrence [27] and bean blossoms were described as "essential intermediaries" between the fungus and the host [13] [25] [26]. Flower contamination by S. sclerotiorum ascospores was associated with disease incidence in bean and canola, where ascospores remained inactive until blossom senescence, which was followed by a rapid colonization of blossoms and subsequent disease when humidity was favorable [28]-[30].

Occasionally, blighted inflorescences with white mycelium of S. sclerotiorum growing from pedicel and peduncle tissues can be observed attached to potato plants in sprinkler irrigated fields in the Columbia Basin of Washington and Oregon. Remnants of the senesced blossom may still be attached to the inflorescence. Evidently ascospores were deposited and then germinated in the flower and the fungus then grew past the abscission ring before the blossom dropped (Figure 2). This illustrates the potential role of contaminated blossoms as an infection 


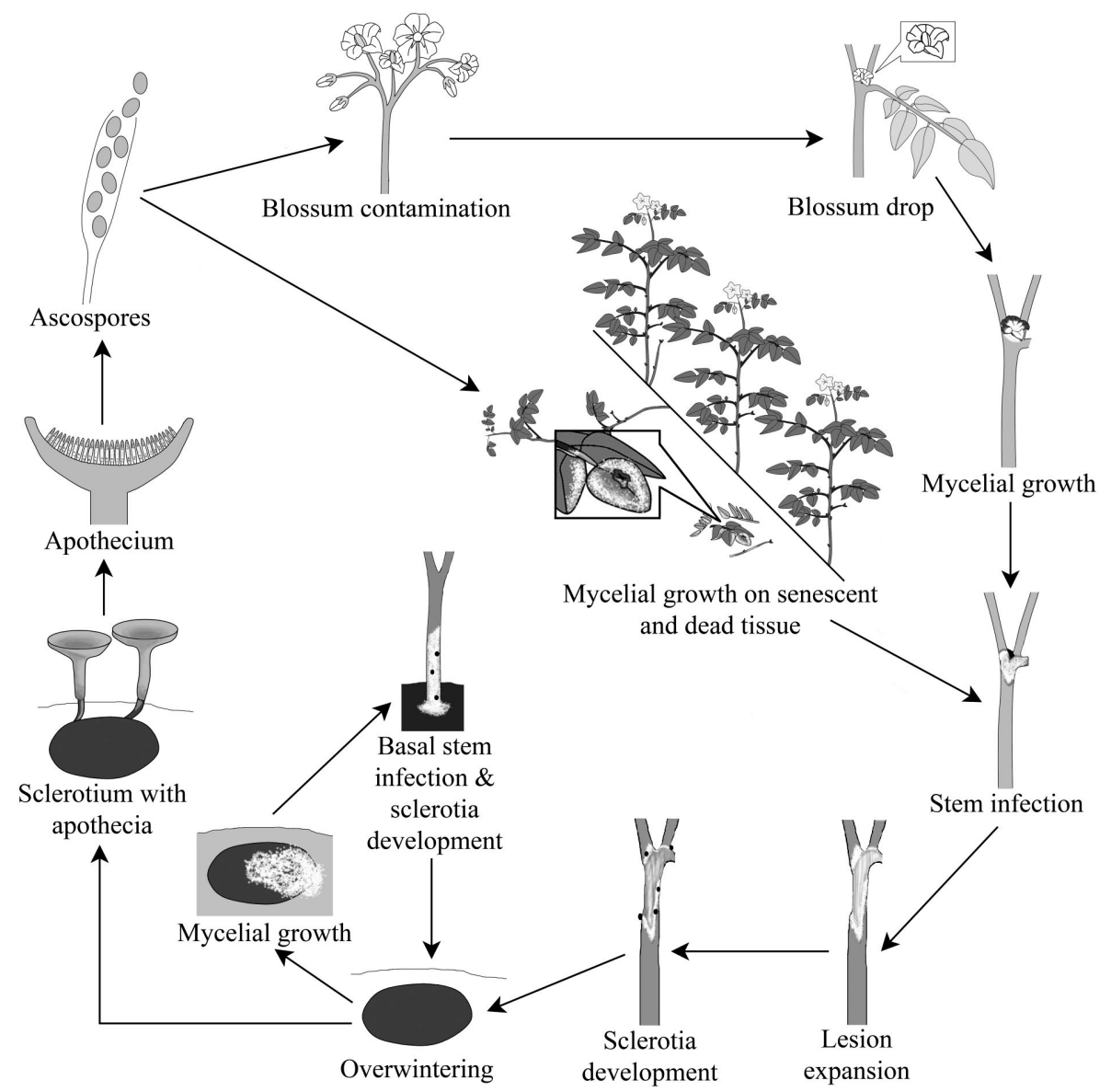

Figure 1. Disease cycle of Sclerotinia sclerotiorum on potato.

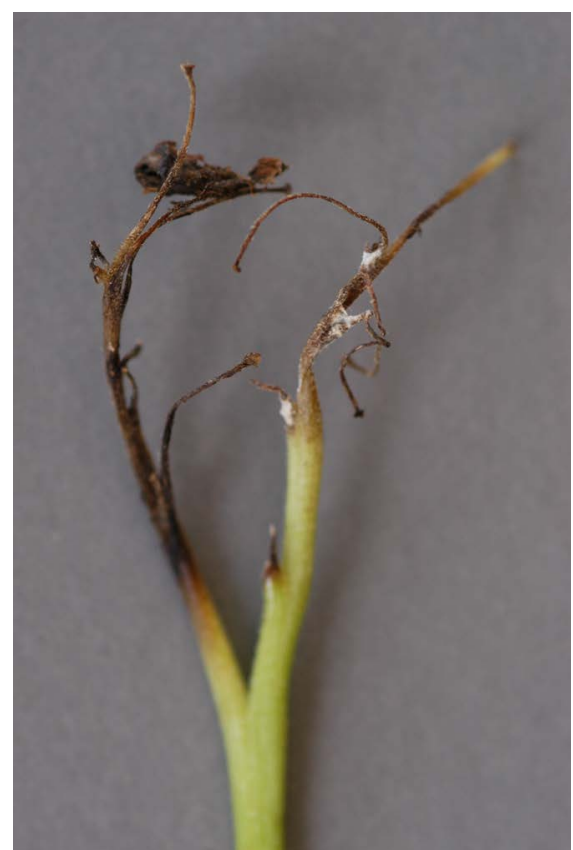

Figure 2. Blighted inflorescences with white mycelium of S. sclerotiorum growing from pedicel and peduncle tissues. 
bridge from a saprophytic to parasitic phase, especially when realizing that most contaminated blossoms abscise and drop into the canopy or to the ground.

Immature apothecia generally first emerge at or shortly after row closure in potato fields in the Columbia Basin. Apothecia are not found after diligent searching in some potato fields, but Sclerotinia stem rot may still develops in many of these fields [19]. Sclerotinia stem rot has not been observed in a few locations in the Columbia Basin were potato fields are isolated from susceptible annual crops by perennial orchards, the Columbia River, and/or non-agricultural land areas [31]. Apothecia present in the potato field, in neighboring potato fields, or in fields of other crops in rotation with potatoes or crops susceptible to S. sclerotiorum are likely sources of ascospore inoculum. Ascospores originating external to a potato field appear to be an important and abundant source of inoculum. Distance of dissemination is not known, but is likely fairly limited based on the large number of susceptible crops grown in the Columbia Basin which may have previously produced sclerotia. Certainly, the closer the inoculum source, including apothecia within a potato field, the greater the number of ascospores impacting and contaminating potato blossoms.

Ascospores are ejected from apothecia and disseminated throughout the Columbia Basin over an extended time period. The greatest numbers of ascospores of $S$. sclerotiorum were captured after row closure and about a week before and continuing a few days after full bloom of primary inflorescences. A hundred percent of the blossoms collected at full bloom of primary inflorescences from potato plants in eight of ten fields were contaminated with $S$. sclerotiorum and initial stem infections originating from airborne ascospores and the subsequent mycelial growth on an organic substrate were not observed until after blossom drop in the Columbia Basin [19].

In an experiment in the Columbia Basin, Petri plates of a semi-selective medium for $S$. sclerotiorum were exposed to capture ascospores at $30-40 \mathrm{~m}$ intervals along a straight-line transected from $60 \mathrm{~m}$ outside of potato fields to $80 \mathrm{~m}$ into fields on opposite sides of six commercial center pivot irrigated fields over two years. Fields were at least 51 ha in area, with a minimum radius of $403 \mathrm{~m}$. Ascospores were captured outside of the potato fields, at the edge of the fields and in the fields. A gradient in numbers of ascospores deposited in Petri dishes over distance was not evident. Equal numbers of ascospores were captured in the windward and leeward sides of the six circles [31]. Ascospores were captured in fields before row closure, which was before apothecia were present in fields, and they were captured in fields where apothecia were not observed to develop in two studies [19] [31]. From these experiments, it is evident that in the Columbia Basin, relatively large numbers of ascospores originate outside as well as within potato fields. Because of the major role that external ascospores play in the infection of potato, sanitation practices to reduce sclerotia in soil, such as a biological control agent or and soil fumigation, likely will not adequately control Sclerotinia stem rot of potato in the Columbia Basin. Extrinsic sources of ascospore inoculum will likely overcome the effects of sanitation within the field. However, when large numbers of viable sclerotia are present in a field usually due to tight rotations with susceptible crops, reducing the numbers of these sclerotia by crop rotation or biological agents may be beneficial in reducing numbers of basal stem infections and numbers of apothecia. Extrinsic sources of ascospores have been shown to be important for epidemics of white mold in bean [32], lettuce drop [33] and Sclerotinia stem rot in rapeseed [34].

\section{Disease Development}

Mycelial mats of $S$. sclerotiorum are usually first observed colonizing senesced blossoms that have dropped on stems in the plant canopy and on the ground 2 to 3 days after blossoms begin dropping from primary flower inflorescences. Infection can occur within 3 days after contact of contaminated blossoms with green tissue. Lesions initially appear on potato stems 14 to 30 days after row closure and 12 to 20 days following full bloom of primary inflorescences of potato in the Columbia Basin (Figure 3) [19] [35]. Time period between row closure and full bloom of primary inflorescences varies depending on cultivar and environment; full bloom of primary inflorescences occurred 5 to 10 days after row closure over a five year period for cultivars Shepody and Ranger Russet in the Columbia Basin. Senescent and dead plant materials on the canopy floor that potentially serve as saprophytic substrates for mycelial mats of S. sclerotiorum are usually scarce prior to row closure, as restricted sun light in the lower canopy appears to be associated with yellowing and senescence of lower leaves. At blossom drop large amounts of senescent and dead plant material may be available and can support numerous mycelial mats on the ground. Potato stems that become lodged and cultivars that have a prostate habit can be severely infected at this time.

Lesions on stems rapidly expand over a period of 4 to 10 days after initial infection. Disease progress curves for incidence of infected stems in fields also increase rapidly over a period of 2 to 3 weeks after symptoms 
Disease Time Line and Progress Curve for Sclerotinia Stem Rot
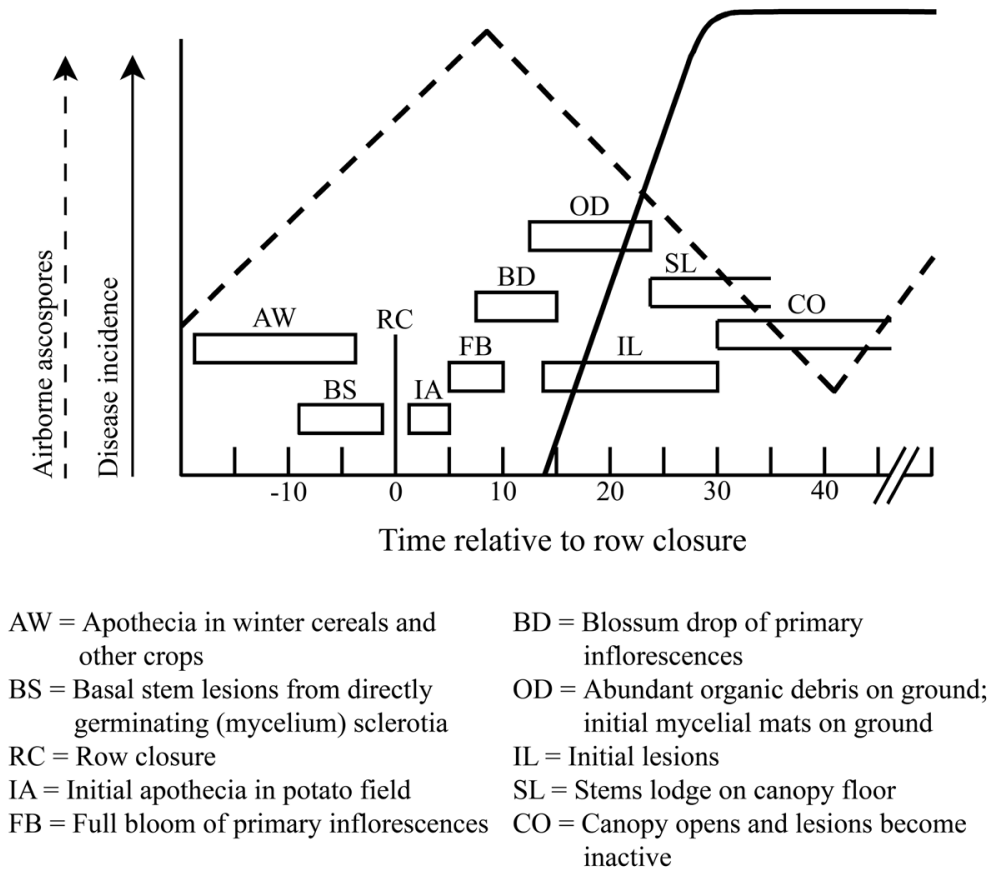

Figure 3. Disease time line and progress curve of Sclerotinia stem rot on potato cultivars Ranger Russet and Shepody in the Columbia Basin of Washington.

initially appear and then usually levels off [19]. The shape of the disease progress curves are consistent with a favoring environment for infection and inoculum arriving on the host as ascospore-contaminated blossoms during blossom drop. The extent of additional infections depends on numbers of stems becoming prostrate on the ground, due to cultivar habit or environment and on frequency of sprinkler irrigation water and rainfall. Sclerotinia stem rot lesions then become less active as the potato canopy begins to open and as less irrigation water is applied due to decreasing plant needs.

The carpogenic germination of sclerotia leading to the production of apothecia and subsequent release and dissemination of ascospores is the result of a sexual recombination. Clonal populations of S. sclerotiorum were repeatedly encountered across $2000 \mathrm{Km}$ in the Canadian Great Plains and the fungus is thought to be primarily homothallic in agricultural areas [36]-[38]. Nevertheless, significant levels of outcrossing sexual recombination have been found to occur in the Pacific Northwest (PNW) and Australia [39] [40]. Additional evidence of outcrossing in populations of the homothallic $S$. sclerotiorum collected from agricultural fields has been demonstrated using linkage disequilibrium decay [41]. Previously, evidence for outcrossing under non-agricultural conditions has been noted [42], while research results have hinted for possible, yet infrequent outcrossing in agricultural conditions [42] [43]. Successful forced outcrossing by Ford et al. (1995) indicated that mycelial compatibility (MCG) and vegetative compatibility (VCG) are governed by different genetic loci. Outcrossing could interfere with the development of stem rot resistant potato cultivars and lead to the distribution of agriculturally disadvantageous traits, such as increased pathogen aggressiveness, as well as resistance to specific fungicides. In line with differing sexual lifestyles between the Canadian Great Plains and the PNW, differences in aggressiveness among isolates were observed in Canada [44], while no differences were observed in the PNW [39].

\section{Disease Management}

Sclerotinia stem rot of potato is best managed by using an integrated approach of combining cultural practices that produce optimum plant foliar development without producing an excessive crop canopy, irrigation management to avoid excessive amounts of irrigation water, and timely applications of fungicides. Potato cultivars with an erect habit usually escape infections from mycelial mats on the soil surface; whereas, cultivars with a 
prostate habit can have high disease incidence.

Resistance-Potato cultivars are not available with resistance to infection. Disease severity can be influenced by cultivar growth habit. For example, cultivars Russet Ranger, Russet Burbank, Russet Norkotah, Shepody, Gem Russet, Atlantic, Alturas Russet, and Umatilla Russet were equally susceptible to Sclerotinia stem rot in controlled, replicated, inoculation experiments (unpublished data). Potato cultivar Gem Russet has a prostate habit and extremely high incidences of Sclerotinia stem rot may occur on this cultivar in the field. With an absence of resistant cultivars, fungicide applications coupled with judicious irrigation management remain the most effective management method.

Fungicide application timing-Control of Sclerotinia stem rot was significantly improved when fungicides thiophanate-methyl (Topsin M $70 \mathrm{WP}$ ) at $1.176 \mathrm{~kg}$ ai/ha, fluazinam (Omega 500F) at $0.280 \mathrm{~kg}$ ai/ha, and boscalid (Endura) at $0.336 \mathrm{~kg}$ ai/ha were applied at full bloom of primary inflorescences compared to applications at closure between rows (row closure) in cultivars Shepody (determinate) and Ranger Russet (indeterminate). Contaminated flower blossoms served as a bridge for infection and fungicides applied before contaminated blossoms dropped on foliage subsequently reduced infections on stems [35]. Similar observations on timing of fungicide application were made when bean flowers were protected with benomyl at full bloom, which prevented white mold development even under optimal environmental conditions [14] [26]. In those studies, benomyl applications made after full bloom of bean failed to provide effective stem rot control because flowers had already acquired the inoculum.

A protective cover of fungicide on potato stems and on potential substrates for saprophytic growth of S. sclerotiorum may both be needed for most effective chemical control. Fungicides applied before full bloom of primary inflorescences are possibly washed from stems and partially degraded before inoculum on colonized blossoms and other substrates is present; whereas, applications at full bloom of primary inflorescences are made just before infection would otherwise occur from fallen contaminated blossoms. Colonization periods (time from inoculation with colonized blossoms to initial stem lesions on potato stems) of three days have been observed in greenhouse experiments. This is consistent with the rapid development of lesions that is often observed soon after contaminated blossoms drop in a humid potato canopy. Initial fungicide application should be made at full bloom of primary inflorescences and not at row closure. This generally occurs 5 to 10 days after row closure in the Columbia Basin. In cultivars that flower over an extended period such as Russet Burbank, initial fungicide application in the Columbia Basin has been most effective about 7 days after row closure.

A difference in application timing of a few days made a difference in the effectiveness of the fungicides. Fungicides applied at row closure did not cover the flower blossoms because blossoms were absent at that time, and fungicides applied at $20 \%$ blossom drop were too late to effectively prevent stem infections from infested blossoms. Data collected two of three years indicated that the window for effective applications was somewhat wider than just at $100 \%$ bloom. Nevertheless, the width of window for the most effective control truncated before $20 \%$ drop of primary flower inflorescences [35].

Applications of boscalid, fluazinam and tiophanate-methyl at full bloom of primary inflorescences, did not vary in efficacy and all three fungicides effectively reduced Sclerotinia stem rot. Thiophanate-methyl was generally less effective than either fluazinam or boscalid in reducing number of stems with lesions when applied at row closure and $10 \%$ bloom of primary inflorescences in two of three years [35].

Foliar fungicides currently registered for Sclerotinia stem rot would not be expected to prevent crown infections from directly germinating sclerotia. This is because the inoculum exists in or on the soil, and soil around the lower stems prevents contact of the fungicide with the stem.

Cultural practices-Severity of Sclerotinia stem rot can be reduced with a combination of practices that limiting potato vine growth such as nitrogen fertilizer management and avoiding over irrigation. Cultural practices need to be employed before infections begin in a field. Irrigation practices that promote long periods of leaf wetness or high relative humidity within the crop canopy should be avoided. Irrigation should be restricted during rainy weather, and on cool, cloudy days, whenever possible.

Biological control-The use of the biological control agent Coniothyrium minitans, a mycoparasite that feeds on sclerotia of $S$. sclerotiorum, to reduce the sclerotia bank in the soil has yielded conflicting results between the regions where experiments have been conducted. In Wisconsin, applications of $C$. minitans have repeatedly reduced white mold incidence in bean fields (W. R. Stevenson, personal communication). In addition, application of C. minitans to soil at seeding time reduced apothecial product from sclerotia under the canopies of bean, canola, wheat, and barley in Alberta [45]. Conversely, numbers of apothecia, number of blossom infections, and 
incidence of stem rot infections were not reduced by applications of $C$. minitans compared to the non-treated control in large, replicated potato plots in a study in the Columbia Basin of Washington State [31]. In the cited study, a commercial preparation of $C$. minitans was applied by chemigation just after the last soil tillage operation in six fields over two years. The application timing was 3 to 5 weeks before row closure in the six fields which should have been sufficient time for the mycoparasite to reduce sclerotia numbers. In addition to the lack of control from not reducing number of sclerotia and subsequent apothecia in the treated plots, the mycoparasite would not prevent airborne ascospores from migrating from non-treated, neighboring and more distant fields. This would likely undo any sanitation effects on sclerotia in the treated field and appears to be more substantial in the PNW than Wisconsin. Additionally, deep tillage and hilling of fields will re-distribute sclerotia across soil profiles, thus bringing to the top sclerotia that have not been exposed to the biological control agent.

\section{Future Research}

Additional improvements in disease management of Sclerotinia stem rot in potato are needed to decrease the expense of fungicides. Questions needing answers to improve control include: What is the quantitative impact of non-blossom, senescing and dead tissues on disease development relative to blossoms? What is the role and prevalence of stem infections initiated by S. sclerotiorum on possible subsequent development of aerial stem rot caused by soft rot bacteria? Does $S$. sclerotiorum infection cause a significant number of entry sites for the bacteria? What is the effective dissemination range for ascospores of S. sclerotiorum? What is the role of protectant fungicides in reducing disease incidence-do they prevent colonization of blossoms, protect green stems from infection by colonized blossoms or both?

Timing of initial fungicide application is based on crop phenology in the Columbia Basin, but development and implementation of disease forecasting models or warning systems would be useful in identifying fields that need or do not need to be treated with fungicide, determine the need and schedule for additional applications, and identify fields and areas that may potentially benefits from application of a biological agent. Potentially useful forecasting models have been developed [11] [12] [27].

Lesion expansion is an important epidemic component for Sclerotinia stem rot [46]. A greater understanding is needed on the quantitative effects of environmental factors such as leaf wetness, humidity, and temperature on rates of lesion expansion on potato genotypes.

Additionally, modifying potato cultivars to provide an upright growth habit and a more aerated canopy should reduce severity of Sclerotinia stem rot in potato as it has in other crops including bean, soybean, canola and peanut [29] [47]-[49]. In commercial potato production, true seed is not used for propagation, yet flowers are consistently produced and fruits are often formed in fields during certain growing seasons. A flowerless cultivar has less disease pressure than flowering cultivars in the PNW and researchers working on identifying sources and mechanisms of resistance to $S$. sclerotiorum may find that reducing blooming to be the alternative to the so-far elusive resistance in potato.

\section{Acknowledgements}

"PPNS \# 0669”, Department of Plant Pathology, College of Agricultural, Human, and Natural Resource Sciences, Agricultural Research Center, Hatch Project No. WNP0678, Washington State University, Pullman, WA 99164-6430, USA.

\section{References}

[1] Boland, G.J. and Hall, R. (1994) Index of Plant Hosts of Sclerotinia sclerotiorum. Canadian Journal of Plant Pathology, 16, 93-108. http://dx.doi.org/10.1080/07060669409500766

[2] Grau, C.R. and Radke, V.L. (1984) Effects of Cultivars and Cultural-Practices on Sclerotinia Stem Rot of Soybean. Plant Disease, 68, 56-58. http://dx.doi.org/10.1094/PD-69-56

[3] Grogan, R.G. and Abawi, G.S. (1975) Influence of Water Potential on Growth and Survival of Whetzelinia sclerotiorum. Phytopathology, 65, 122-128. http://dx.doi.org/10.1094/Phyto-65-122

[4] Gutierrez, W.A. and Shew, H.D. (1998) Identification and Quantification of Ascospores as the Primary Inoculum for Collar Rot of Greenhouse-Produced Tobacco Seedlings. Plant Disease, 82, 485-490.

http://dx.doi.org/10.1094/PDIS.1998.82.5.485 
[5] Keay, M.A. (1939) A Study of Certain Species of the Genus Sclerotinia. Annals of Applied Biology, 26, 227-246. http://dx.doi.org/10.1111/j.1744-7348.1939.tb06968.x

[6] Natti, J.J. (1971) Epidemiology and Control of Bean White Mold. Phytopathology, 61, 669-674. http://dx.doi.org/10.1094/Phyto-61-669

[7] Purdy, L.H. (1979) Sclerotinia Sclerotiorum-History, Diseases and Symptomatology, Host Range, Geographic Distribution, and Impact. Phytopathology, 69, 875-880. http://dx.doi.org/10.1094/Phyto-69-875

[8] Steadman, J.R. (1979) Control of Plant-Diseases Caused by Sclerotinia Species. Phytopathology, 69, 904-907. http://dx.doi.org/10.1094/Phyto-69-904

[9] Kohn, L.M. (1979) Delimitation of the Economically Important Plant Pathogenic Sclerotinia Species. Phytopathology, 69, 881-886. http://dx.doi.org/10.1094/Phyto-69-881

[10] Dillard, H.R., Ludwig, J.W. and Hunter, J.E. (1995) Conditioning Sclerotia of Sclerotinia sclerotiorum for Carpogenic Germination. Plant Disease, 79, 411-415. http://dx.doi.org/10.1094/PD-79-0411

[11] Clarkson, J.P., Phelps, K., Whipps, J.M., Young, C.S., Smith, J.A. and Watling, M. (2004) Forecasting Sclerotinia Disease on Lettuce: Toward Developing a Prediction Model for Carpogenic Germination of Sclerotia. Phytopathology, 94, 268-279. http://dx.doi.org/10.1094/PHYTO.2004.94.3.268

[12] Sun, P. and Yang, X.B. (2000) Light, Temperature, and Moisture Effects on Apothecium Production of Sclerotinia sclerotiorum. Plant Disease, 84, 1287-1293. http://dx.doi.org/10.1094/PDIS.2000.84.12.1287

[13] Schwartz, H.F. and Steadman, J.R. (1978) Factors Affecting Sclerotium Populations of, and Apothecium Production by Sclerotinia sclerotiorum. Phytopathology, 68, 383-388. http://dx.doi.org/10.1094/Phyto-68-383

[14] Steadman, J.R. (1983) White Mold—A Serious Yield-Limiting Disease of Bean. Plant Disease, 67, 346-350. http://dx.doi.org/10.1094/PD-67-346

[15] Phillips, A.J.L. (1987) Carpogenic Germination of Sclerotia of Sclerotinia sclerotiorum: A Review. Phytophylactica, 19, 279-283.

[16] Ben-Yephet, Y., Genizi, A. and Siti, E. (1993) Sclerotial Survival and Apothecial Production by Sclerotinia sclerotiorum Following Outbreaks of Lettuce Drop. Phytopathology, 83, 509-513. http://dx.doi.org/10.1094/Phyto-83-509

[17] McCartney, H.A. and Lacey, M.E. (1991) The Relationship between the Release of Ascospores of Sclerotinia sclerotiorum, Infection and Disease in Sunflower Plots in the United Kingdom. Grana, 30, 486-492. http://dx.doi.org/10.1080/00173139109432015

[18] McCartney, H.A. and Lacey, M.E. (1992) Release and Dispersal of Sclerotinia Ascospores in Relation to Infection. Brighton Crop Protection Conference: Pests and Diseases, 3A-2, 109-116.

[19] Atallah, Z.K. and Johnson, D.A. (2004) Development of Sclerotinia Stem Rot in Potato Fields in South-Central Washington. Plant Disease, 88, 419-423. http://dx.doi.org/10.1094/PDIS.2004.88.4.419

[20] Abawi, G.S. and Grogan, R.G. (1979) Epidemiology of Diseases Caused by Sclerotinia Species. Phytopathology, 69, 899-904. http://dx.doi.org/10.1094/Phyto-69-899

[21] Ben-Yephet, Y. and Bitton, S. (1985) Use of a Selective Medium to Study the Dispersal of Ascospores of Sclerotinia sclerotiorum. Phytoparasitica, 13, 33-40. http://dx.doi.org/10.1007/BF02994435

[22] Stelfox, D., Williams, J.R., Soehngen, U. and Topping, R.C. (1978) Transport of Sclerotinia sclerotiorum Ascospores by Rapeseed Pollen in Alberta. Plant Disease Reporter, 62, 576-579.

[23] Williams, J.R. and Stelfox, D. (1979) Dispersal of Ascospores of Sclerotinia sclerotiorum in Relation to Sclerotinia Stem Rot of Rapeseed. Plant Disease Reporter, 63, 395-399.

[24] Caesar, A.J. and Pearson, R.C. (1983) Environmental Factors Affecting Survival of Ascospores of Sclerotinia sclerotiorum. Phytopathology, 73, 1024-1030. http://dx.doi.org/10.1094/Phyto-73-1024

[25] Abawi, G.S. and Grogan, R.G. (1974) Ascospores of Whetzelinia sclerotiorum as Primary Inoculum Causing White Mold of Beans n New York. Phytopathology, 64, 578-578.

[26] Abawi, G.S., Polach, F.J. and Molin, W.T. (1975) Infection of Bean by Ascospores of Whetzelinia sclerotiorum. Phytopathology, 65, 673-678. http://dx.doi.org/10.1094/Phyto-65-673

[27] Turkington, T.K. and Morrall, R.A.A. (1993) Use of Petal Infestation to Forecast Sclerotinia Stem Rot of Canola: The Influence of Inoculum Variation over the Flowering Period and Canopy Density. Phytopathology, 83, 682-689. http://dx.doi.org/10.1094/Phyto-83-682

[28] Boland, G.J. and Hall, R. (1988) Epidemiology of Sclerotinia Stem Rot of Soybean in Ontario. Phytopathology, 78, 1241-1245. http://dx.doi.org/10.1094/Phyto-78-1241

[29] Coyne, D.P., Steadman, J.R. and Anderson, F.N. (1974) Effect of Modified Plant Architecture of Great Northern Dry Bean Varieties (Phaseolus vulgaris) on White Mold Severity, and Components of Yield. Plant Disease Reporter, 58, 
379-382.

[30] Lefol, C. and Morrall, R.A.A. (1996) Immunofluorescent Staining of Sclerotinia Ascospores on Canola Petals. Canadian Journal of Plant Pathology, 18, 237-241. http://dx.doi.org/10.1080/07060669609500618

[31] Hammond, C. and Johnson, D.A. (2005) Origin of Ascospores of Sclerotinia sclerotiorum for White Mold Development in Potato Fields in the Columbia Basin. American Journal of Potato Research, 82, 72.

[32] Boland, G.J. and Hall, R. (1987) Epidemiology of White Mold of White Bean in Ontario. Canadian Journal of Plant Pathology, 9, 218-224. http://dx.doi.org/10.1080/07060668709501877

[33] Patterson, C.L. and Gorgan, R.G. (1985) Differences in Epidemiology and Control of Lettuce Drop Caused by Sclerotinia minor and S. sclerotiorum. Plant Disease, 69, 766-770. http://dx.doi.org/10.1094/PD-69-766

[34] Morrall, R.A.A. and Dueck, J. (1982) Epidemiology of Sclerotinia Stem Rot of Rapeseed in Saskatchewan. Canadian Journal of Plant Pathology, 4, 161-168. http://dx.doi.org/10.1080/07060668209501319

[35] Johnson, D.A. and Atallah, Z.K. (2006) Timing Fungicide Applications for Managing Sclerotinia Stem Rot of Potato. Plant Disease, 90, 755-758. http://dx.doi.org/10.1094/PD-90-0755

[36] Hambleton, S., Walker, C. and Kohn, L.M. (2002) Clonal Lineages of Sclerotinia sclerotiorum Previously Known from Other Crops Predominate in 1999-2000 Samples from Ontario and Quebec Soybean. Canadian Journal of Plant Pathology, 24, 309-315. http://dx.doi.org/10.1080/07060660209507014

[37] Kohli, Y. and Kohn, L.M. (1998) Random Association among Alleles in Clonal Populations of Sclerotinia sclerotiorum. Fungal Genetics and Biology, 23, 139-149. http://dx.doi.org/10.1006/fgbi.1997.1026

[38] Kohli, Y., Morrall, R.A.A., Anderson, J.B. and Kohn, L.M. (1992) Local and Trans-Canadian Clonal Distribution of Sclerotinia sclerotiorum on Canola. Phytopathology, 82, 875-880. http://dx.doi.org/10.1094/Phyto-82-875

[39] Atallah, Z.K., Larget, B., Chen, X. and Johnson, D.A. (2004) High Genetic Diversity, Phenotypic Uniformity, and Evidence of Outcrossing in Sclerotinia sclerotiorum in the Columbia Basin of Washington State. Phytopathology, 94, 737-742. http://dx.doi.org/10.1094/PHYTO.2004.94.7.737

[40] Sexton, A.C. and Howlett, B.J. (2004) Microsatellite Markers Reveal Genetic Differentiation among Populations of Sclerotinia sclerotiorum from Australian Canola Fields. Current Genetics, 46, 357-365. http://dx.doi.org/10.1007/s00294-004-0543-3

[41] Attanayake, R.N., Tennekoon, V., Johnson, D.A., Porter, L.D., del Rio-Mendoza, L., Jiang, D. and Chen, W. (2014) Inferring Outcrossing in the Homothallic Fungus Sclerotinia sclerotiorum Using Linkage Disequilibrium Decay. Heredity, 113, 353-363. http://dx.doi.org/10.1038/hdy.2014.37

[42] Kohn, L.M. (1995) The Clonal Dynamic in Wild and Agricultural Plant-Pathogen Populations. Canadian Journal of Botany, 73, 1231-1240. http://dx.doi.org/10.1139/b95-383

[43] Cubeta, M.A., Cody, B.R., Kohli, Y. and Kohn, L.M. (1997) Clonality in Sclerotinia sclerotiorum on Infected Cabbage in Eastern North Carolina. Phytopathology, 87, 1000-1004. http://dx.doi.org/10.1094/PHYTO.1997.87.10.1000

[44] Kohli, Y., Brunner, L.J., Yoell, H., Milgroom, M.G., Anderson, J.B., Morrall, R.A.A. and Kohn, L.M. (1995) Clonal Dispersal and Spatial Mixing in Populations of the Plant Pathogenic Fungus Sclerotinia sclerotiorum. Molecular Ecology, 4, 69-77. http://dx.doi.org/10.1111/j.1365-294X.1995.tb00193.x

[45] McLaren, D.L., Huang, H.C. and Rimmer, S.R. (1996) Control of Apothecial Production of Sclerotinia sclerotiorum by Coniothyrium minitans and Talaromyces flavus. Plant Disease, 80, 1373-1378. http://dx.doi.org/10.1094/PD-80-1373

[46] Berger, R.D., Bergamin Filho, A. and Amorim, L. (1997) Lesion Expansion as an Epidemic Component. Phytopathology, 87, 1005-1013. http://dx.doi.org/10.1094/PHYTO.1997.87.10.1005

[47] Butzler, T.M., Bailey, J. and Beute, M.K. (1998) Integrated Management of Sclerotinia Blight in Peanut: Utilizing Canopy Morphology, Mechanical Pruning, and Fungicide Timing. Plant Disease, 82, 1312-1318. http://dx.doi.org/10.1094/PDIS.1998.82.12.1312

[48] Fuller, P.A., Steadman, J.R. and Coyne, D.P. (1984) Enhancement of White Mold Avoidance and Yield in Dry Beans by Canopy Elevation. HortScience, 19, 78-79.

[49] Steadman, J.R., Coyne, D.P. and Cook, G.E. (1973) Reduction of Severity of White Mold Disease on Great-Northern Beans by Wider Row Spacing and Determinate Plant-Growth Habit. Plant Disease Reporter, 57, 1070-1071. 
Scientific Research Publishing (SCIRP) is one of the largest Open Access journal publishers. It is currently publishing more than 200 open access, online, peer-reviewed journals covering a wide range of academic disciplines. SCIRP serves the worldwide academic communities and contributes to the progress and application of science with its publication.

Other selected journals from SCIRP are listed as below. Submit your manuscript to us via either submit@scirp.org or Online Submission Portal.
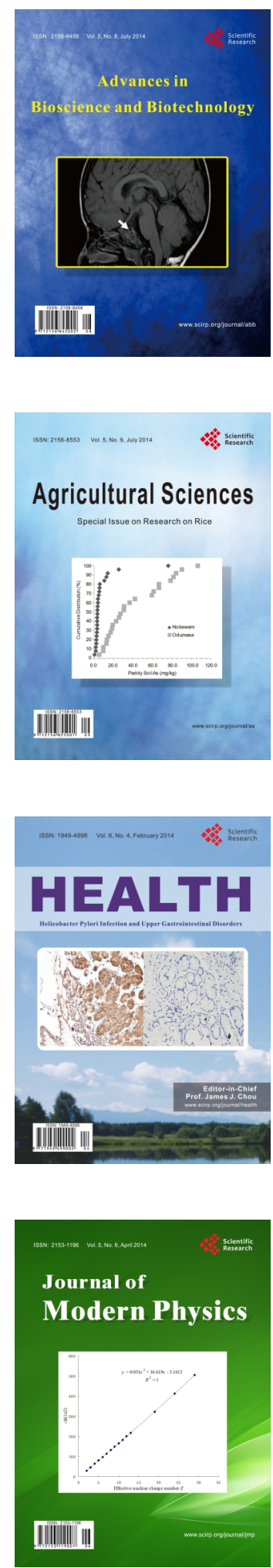
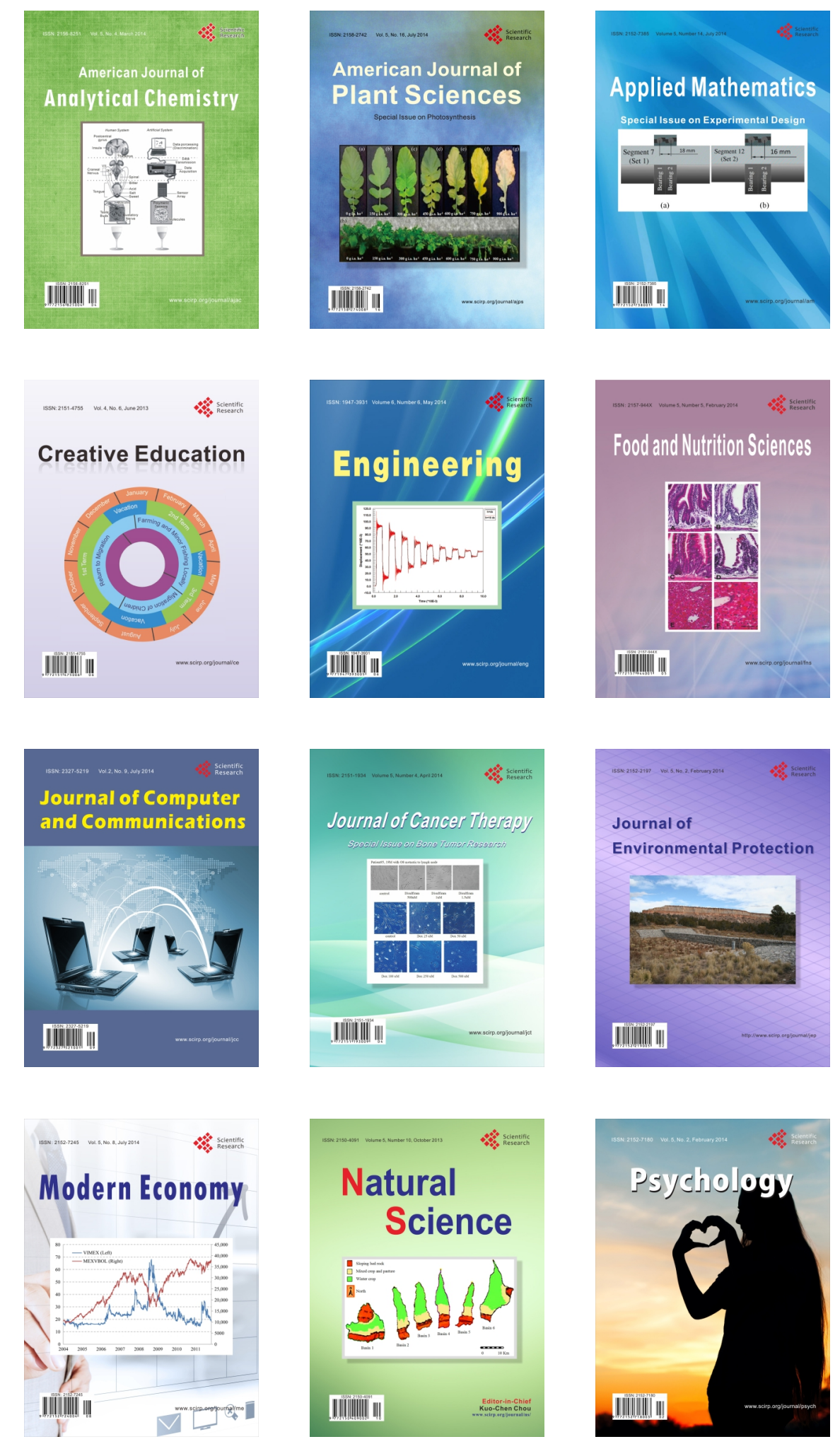